\title{
The Hydrodynamic Investigation of the Structures on the Serbian Sector of the River Tisza
}

\section{A szerbiai Tisza-szakasz mütárgyainak hidrodinamikai vizsgálata}

The river crossing structures in case of failure, damage or improper hydraulics shaping can be the source of a disaster risk. In this article, the result of modelling on problems of two structures is presented which are located on the Tisza section between the Hungarian border and the mouth. The Dam of Novi Bečej in case of normal operation does not cause unbeneficial water level heightening or does not cause a harmful low water situation; nevertheless if failure or deliberate damage occurs, it can cause significant problems both in the low and high water periods.

Keywords: disaster risk, modelling, construction errors

A folyókat keresztező mütárgyak meghibásodás, rongálódás vagy helytelen hidraulikai kialakitás esetén katasztrófaveszély kialakulásának forrásai lehetnek. A cikkben, a magyar határ és a dunai torkolat közötti Tisza-szakaszon lévő két mütárgy okozta probléma modellezéssel történő vizsgálatának eredményeit mutatom be. Az adai közúti híd, hidraulikai szempontból kedvezőtlen kialakitása miatt jelent lefolyási akadályt. A törökbecsei (Novi Bečej) duzzasztó normál müködés esetén nem okoz kedvezőtlen visszaduzzasztást vagy károsan alacsony vizállást, azonban meghibásodás vagy szándékos rongálás esetén jelentős problémát okozhat mind kisvizkor, mind nagyvízkor.

Kulcsszavak: katasztrófaveszély, modellezés, épitési hibák

General Directorate of Water Management, e-mail: labdy.jeno@ovf.hu, ORCID: 0000-0002-9582-1316

National University of Public Service, e-mail: toth.rudolf@chello.hu, ORCID: 0000-0002-6013-7899 


\section{Introduction}

The phrase "water has no borders" is well-known. In Hungary we very often experience the truth of this, because most of our surface water comes from abroad, ${ }^{3}$ on an average of $109 \mathrm{~km}^{3}$ per year. The precipitation is a little bit more than half of this amount, $56 \mathrm{~km} .{ }^{3}$ Nevertheless, half of this evaporates, so the main important water resource - by the ground water - originates from the surrounding countries. An additional issue is, that this water supply is not permanent, sometimes too much, sometimes too little amount of water arrives from the catchment areas. The water retention (e.g. implementing of dams) can be a solution of the question of low water situation. The developing of the hydraulic corridor, reconstruction of the levees according to the national standards ${ }^{4}$ and the implementation of flood control reservoirs can be used for flood prevention. To ensure "space for the river", it is significant to avoid establishing construction in the riverbed which can be an obstacle in the flow. ${ }^{5}$ In this manner the constructions crossing the streams have to be analysed - nowadays by hydraulic models - and it has to be determined, how they influence the runoff conditions. The Bridge of Ada is a good sample of this, its tracking section in the flooded area ${ }^{6}$ was implemented with only a few narrow bays for the water flow.

The other controlled structure is the Dam of Novi Bečej, its standard operation highly supports the avoidance of the low water level, but in case of failure or wilful abuse, it can be an obstacle in the flow or the termination of the damming can cause adverse low water level on the Hungarian section of the River Tisza.

The actuality of this question arises from the fact, that 20 years ago - which is a very short period historically - the NATO bombed Serbia. The attacks focused on the transport, energy and communication infrastructure. There were several bridges among the destroyed structures, its destroying not only blocked the undisturbed transport activities, but fell into the river, which also meant flood risk as an obstacle in the flow.

The Dam of Novi Bečej was analysed by me - because it is a bridge as well -, there were real chances, that it was destroyed. The bombing targeted mainly the transport links in Serbia. The leadership of water management on those days effectively analysed the possibility of this. As all of our big streams come from the surrounding countries, hence all forthcoming natural disasters or situations of war which caused flood risk or water scarcity have a significant influence on Hungary, as well. For this reason all research concerning water has to be implemented with a river basin approach, i.e. the river sections in the surrounding countries have to be involved into the analysis.

The importance of the analysis of the structures in the riverbed is highlighted by the New Vásárhelyi Plan, ${ }^{7}$ which is the answer of the water sector on the problems caused by the floods.

According to this concept, two technical interventions solve the channelling of the floods. On the one hand, the floods have to be channelled as fast as possible, on the other hand

\footnotetext{
National Atlas of Hungary 2018, 70-71.

74/2014 (XII. 23.) Regulation of the Ministry of Interior.

83/2014 (III. 14.) Government Decree.

"The flooded area" means the area between the levee and the main riverbed.

General flood management project of the Tisza Valley.
} 
the adverse excess water has to be deflated into newly built emergency reservoirs and after the termination of the flood situation, it has to be deflated back to the river. "Channelled as fast as possible" means that the capacity of the flood bed is increased, with reasonable forest and field management or rather the structures which blocked the channelling of the water are removed, not allowing their implementation. A typical example of this is the Bridge of Ada.

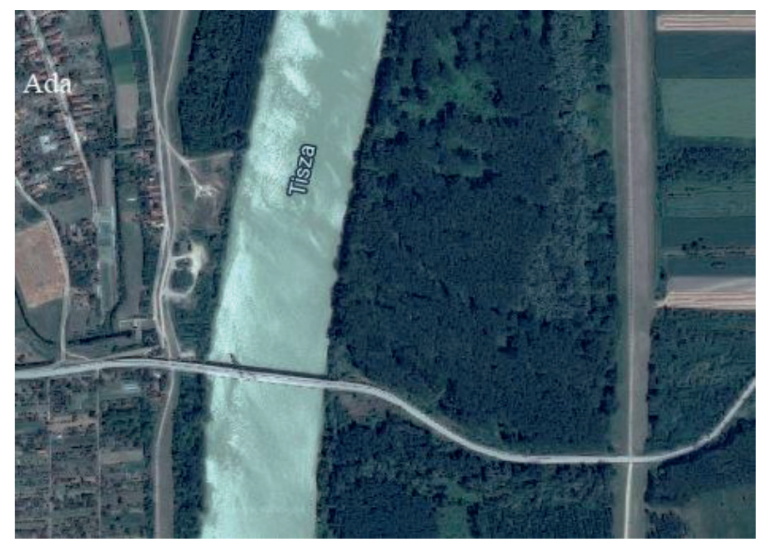

Picture 1. The Bridge of Ada on the River Tisza

Source: Google Maps.



Picture 2. The Dam of Novi Bečej on the River Tisza

Source: Google Maps.

On the Pictures 1 and 2 it can be seen the location of the two structures. In case of the Bridge of Ada, the tracking section in the flooded area is visibly blocking a significant part of the flood bed. 


\section{A Short Introduction of the Software Used for Modelling and Its Usage}

The importance in the military and disaster management of the hydrodynamic and other modelling software shows that the US Army Corps of Engineer Hydrologic Engineering Centre (HEC) developed a special software pack for the US Army, which is suitable to solve all modelling task concerning water. The software made by HEC - according the local law - is free of charge and this fact offers special opportunities for the engineers work worldwide. The product made from the money of the US taxpayer is not allowed to sale on a commercial basis.

The first version of the software was presented in 1968, like the first such product in the US. Nowadays, the 2D version was presented, as well; however, the 1D version is also tolerable for my targeted analysis.

A free software for a given task always awakes doubt. In case of the HEC software, the development work is very costly and effective, thus they have a high quality. Due to the wide range of domestic usage, a lot of experience was aggregated, the uploading of the basis data from the domestic database has already been a solved question. According to the experience of the long term sectorial usage, it can be declared that the RAS ${ }^{8}$ module of the HEC software pack is masterfully capable to implement the targeted tasks.

It is a lucky coincidence, that the Lower Tisza District Water Directorate and their Serbian partners $^{9}$ - in the TRMODELL IPA Cross-border Cooperation Programme project - measured the whole section of the Tisza River in Serbia, therefore I can use new geometrica ${ }^{10}$ data for the model.

In the course of calibration, the Manning coefficient was adjusted. Its values can be set cross-section by cross-section depending on the riverbed roughness. This is the most common method of the calibration, which can be found in several scientific publications. ${ }^{11}$

On the modelling process, I analyse the low and high water situation which happened in the past. I take into consideration the constructing of the Bridge of Ada, or rather if the Dam of Novi Bečej did not work properly. I analyse both constructions in low and high water situation as well. In case of the bridge, this analysis should have been done before the implementation. In case of the dam, the effect of the different damages can be measured, having supported the protection activities.

\section{Investigation of the Bridge of Ada}

The shaping of the Bridge of Ada - according to the set agreement, which was contracted in 1955 between Hungary and Yugoslavia - had to be cross-checked with the Hungarian partners. This did not happen, the analysis of the bridge could only be done after its implementation.

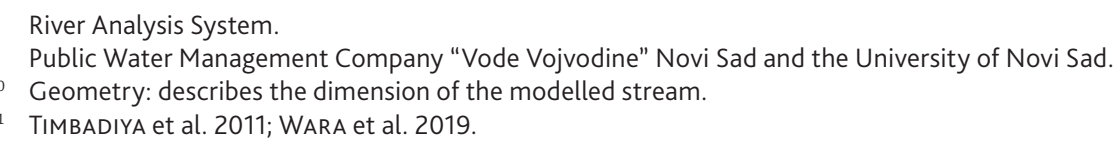


The tracking section of the bridge in the flooded area is approximately $500 \mathrm{~m}$ long, 3 pieces of $6 \mathrm{~m}$ wide bay was implemented instead of the planned 11 pieces. This way, this structure blocked $96.4 \%$ of this part of the cross-section.

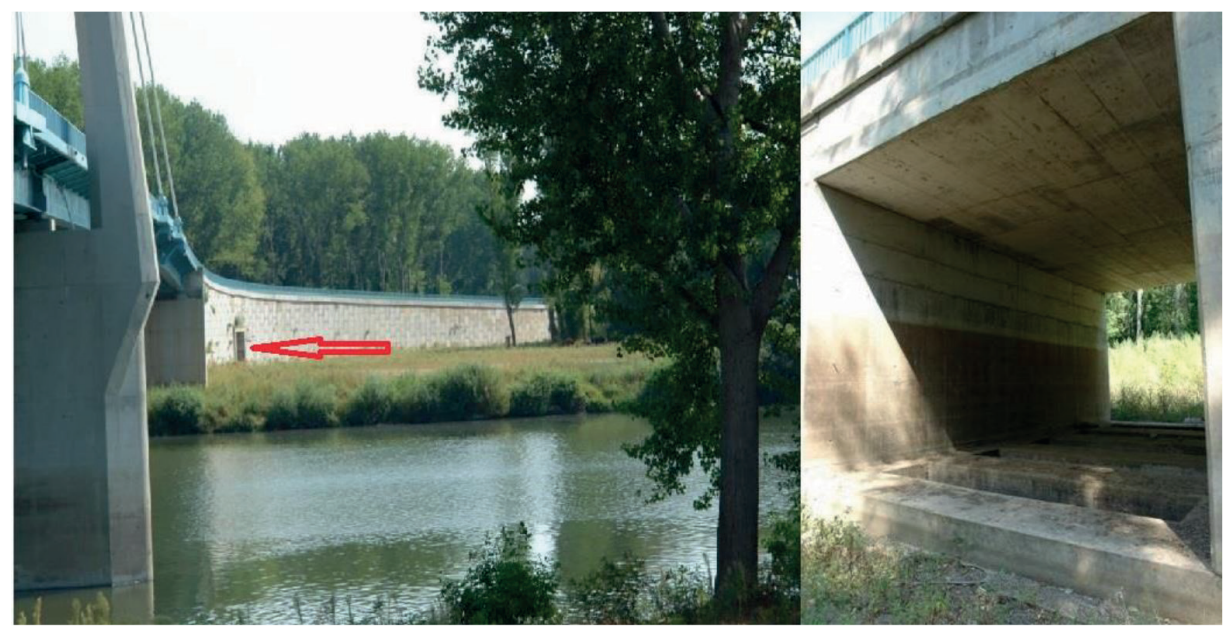

Picture 3. The picture of the openings on the Bridge of Ada

Source: Photo made by the author.

On the left hand side of Picture 3, a red arrow shows the location of one of the openings. In the original geometry of the Tisza HEC-RAS model, there were 11 pieces of bays, even though only 3 pieces were built. Before the execution, this mistake was corrected.

Only a part of the whole Tisza model was used for the executions, between the crosssections $192+030$ and $9+900 \mathrm{fkm},{ }^{12}$ as well as the Hungarian section of the River Maros. As a significant load, the flood wave of 2006 was used, which generated the historical maximum water level (Szeged 1,009 cm). The hourly discharge from Algyő and Makó, as well as the hourly water level from Titel were the input data. The executions were done with two scenarios:

- in case of an overgrown flooded area

- in case of a maintained flooded area

$12 \mathrm{fkm}=$ distance from the mouth in kilometre. 
The results are included in Table 1.

Table 1. Spreadsheet No. 1 - results of the modelling

\begin{tabular}{|c|c|c|c|c|c|c|}
\hline Name & $\begin{array}{l}\text { Upstream } \\
\text { (fkm) }\end{array}$ & $\begin{array}{c}\text { Downstream } \\
\text { (fkm) }\end{array}$ & $\begin{array}{c}\text { Free } \\
\text { surface } \\
\text { mainstream } \\
(\mathbf{m})\end{array}$ & $\begin{array}{c}\text { Wet area } \\
\text { in mainstream } \\
\text { at summit } \\
\text { level } \\
\left(\mathrm{m}^{2}\right)\end{array}$ & $\begin{array}{c}\text { Damming } \\
\text { (real) } \\
1 . \\
\text { (cm) }\end{array}$ & $\begin{array}{c}\text { Damming } \\
\text { with } \\
\text { maintaned } \\
\text { flooded area } \\
1 . \\
\text { (cm) }\end{array}$ \\
\hline $\begin{array}{l}\text { Bridge of Algyö } \\
\text { (road-bridge) }\end{array}$ & $191+820$ & $191+800$ & 145 & 2312 & 0 & 0 \\
\hline $\begin{array}{l}\text { Bertalan Bridge Szeged } \\
\text { (road-bridge) }\end{array}$ & $174+410$ & $174+690$ & 229 & 2526 & 2 & 3 \\
\hline $\begin{array}{l}\text { Downtown Bridge Szeged } \\
\text { (road-bridge) }\end{array}$ & $173+610$ & $173+590$ & 172 & 2716 & 2 & 4 \\
\hline $\begin{array}{l}\text { Bridge of Novi Kneževac } \\
\text { (road-bridge) }\end{array}$ & $141+310$ & $140+290$ & 182 & 2531 & 1 & 1 \\
\hline $\begin{array}{l}\text { Bridge of Zenta } \\
\text { (road-bridge) }\end{array}$ & $121+480$ & $121+460$ & 180 & 2449 & 0 & 0 \\
\hline $\begin{array}{l}\text { Bridge of Ada } \\
\text { (road-bridge) }\end{array}$ & $99+421$ & $99+401$ & 189 & 2932 & 0 & 0 \\
\hline Dam of Novi Bečej & $63+420$ & $63+380$ & - & - & 5 & 4 \\
\hline \begin{tabular}{|l}
$\begin{array}{l}\text { Bridge of Žabalj } \\
\text { (road-bridge) }\end{array}$ \\
\end{tabular} & $36+950$ & $36+930$ & 220 & 2662 & 1 & 0 \\
\hline
\end{tabular}

Source: Drawn by the author.

In spreadsheet No. 1, it can be seen that the damming effect is higher in case of maintained flooded area, but it is not significant even in this situation. Although this is a little bit surprising, the experiences on the discharge measurement on the Lower Tisza section are that the flooded area does not have a too big role in several location in water transporting. In the evaluated cross-sections, there is enough wet-area under the structure of the bridge to drain the water.

\section{Investigation of the Dam of Novi Bečej}

The Dam of Novi Bečej was built in the cross-section $63 \mathrm{~km}$, presented in $1977 .{ }^{13} \mathrm{It}$ dams in low and medium water level situation, otherwise during a flood it is fully open. In case of normal operation, it influences the water level up to Csongrád. The most outstanding change was in Szeged, where the lowest water level was $-250 \mathrm{~cm}$, afterwards the values stay in the positive range. I evaluated the failure of the dam (or wilful abuse) in case of two hydraulic regimes:

- no damming due to failure or wilful abuse of the dam in case of a low water situation

- partial opening of shuttles or fully blocked bays due to failure or wilful abuse of the dam in case of a flood

13 Hungarian-Serbian-Montenegrin Water Management Committee 2006. 


\section{Evaluation in Case of Low Water}

I used the same river sections for the executions as for the Bridge of Ada. I had to modify the geometry in this case, as well, due to the dam was in the HEC-RAS model as a bridge. Exclusively, this does not have any role in case of a flood evaluation, because the locking structures (which were not in the original geometry) were fully opened. They have to be built into the model during the evaluation in case of low water situation. As a significant load, I used the data from 10 August to 31 October of 2000. This was the summer with the lowest water level since the damming was started. The hourly discharge from Algyö and Makó, as well as the hourly water level from Titel were the input data. The observed data from gauge in Szeged was used for the calibration; I research how high the water level would have been in the area of Szeged, if the dam was out of order due to failure or wilful abuse.

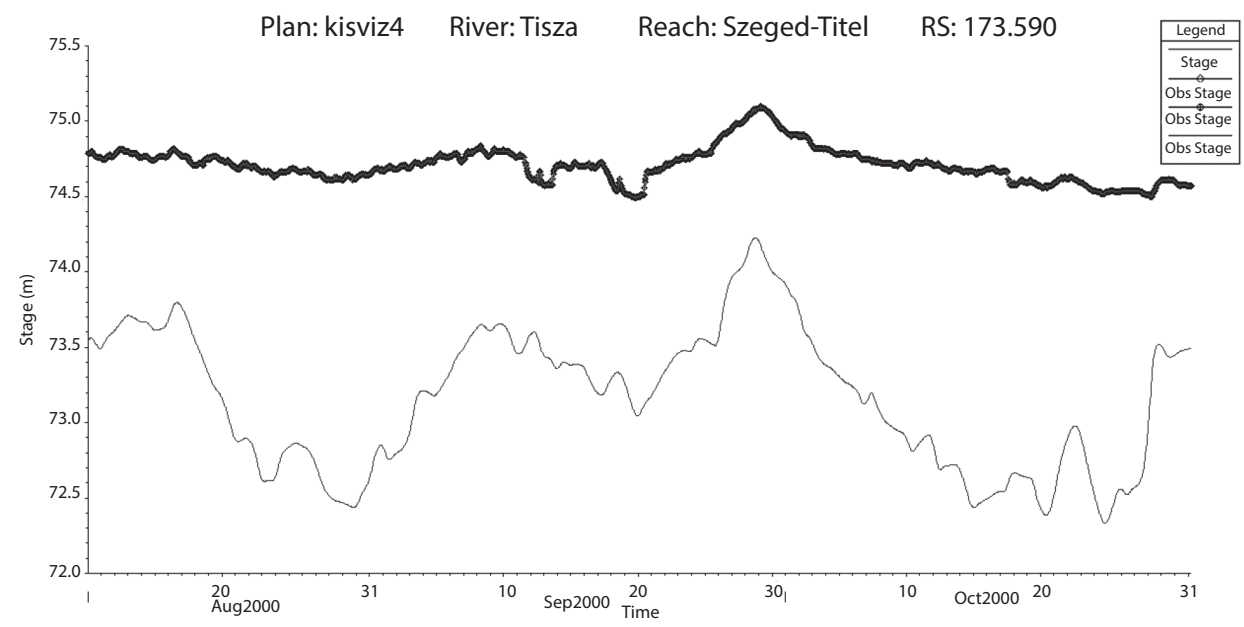

Figure 1. The output graph of the A HEC-RAS model

Source: Executed by the author.

The bold black line of the hydrograph shows the measured values of the gauge in Szeged with the normal functionality of the dam, the narrow blue line shows the hypothetical situation without damming. In an extreme low water situation, the lack of damming can decrease the water level with 2.2 metres. In this hypothetical situation, the circumstances of the navigation are changed, as well as the fixing and entering of the several floating houses also become harder. The extreme low water level in the Tisza should be influenced on the lower section of the Maros, which makes impossible the water abstraction (the pumps inlet cannot reach the water). On the Serbian side, the gravitational water output is impossible, which needs high water level in the reservoir section. Irrigation of huge areas has to be stopped, during the dry period. 


\section{Evaluation in Case of a Flood}

The same geometry was used for the execution as presented before. As input data, the hourly discharge from Algyő and Makó, as well as the hourly water level from Titel were used. I used the data row of flood from 2006, which cause the historical maximum levels, so it was the determining high water situation on the Lower Tisza sections (e.g. Szeged, 1,009 cm).

The model executions were done according to two scenarios:

- due to the failure of the dam (or wilful abuse), 3 of the 7 shuttles cannot be opened

- due to the failure of the dam (or wilful abuse), all of the shuttles and the navigation lock cannot be opened

The results of the model executions show - in case of 3 shuttle failures - the water level arising $\sim 5 \mathrm{~cm}$ on the upstream, which decrease to marginal up to Szeged. If the dam is fully blocked, this means $96 \mathrm{~cm}$ water level rising on the upstream of the structure.

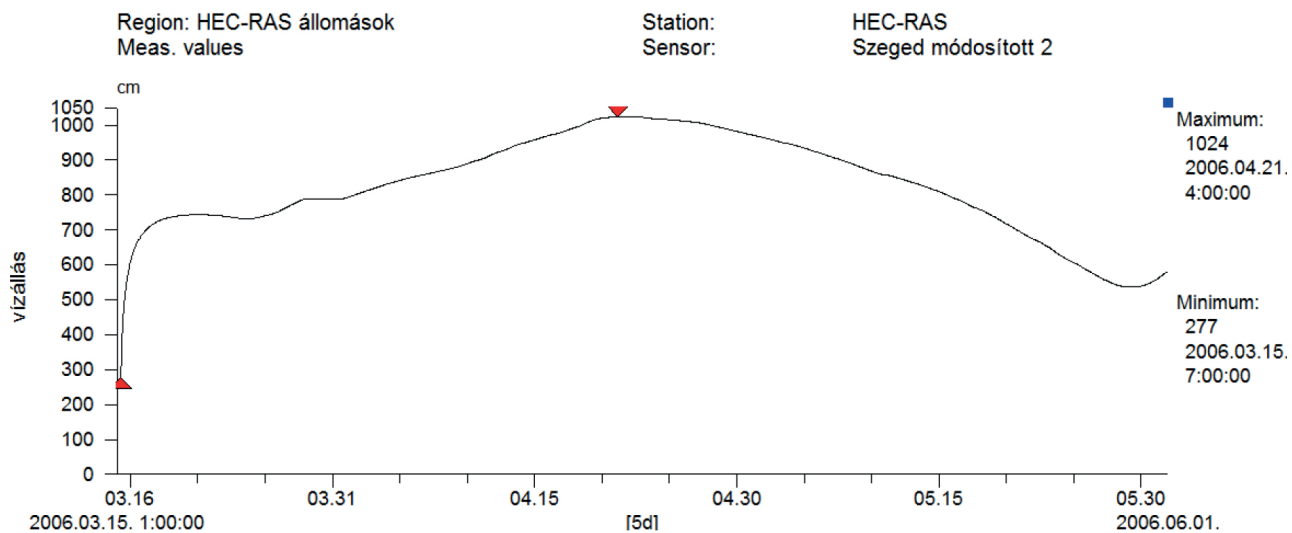

Figure 2. The changing of the water level in the Szeged section in case of a fully blocked dam

Source: Executed by the author.

On the hydrograph (Figure 2), it can be seen the water level rising in the Szeged section, which is $15 \mathrm{~cm}$ (compared with the real observed value $-1,009 \mathrm{~cm}$ ) in case of the total failure of the dam.

\section{Summary, Conclusions}

Although during the planning and building of the Bridge of Ada the necessary engineering solutions were not used (a bridge on the flooded area, which does not make up an obstacle in the riverbed), it can be concluded according to the modelling due to the fortunate location, it has 
no significant influence on the water transporting capacity. It can also be concluded, that this influence can be increasing if the Vásárhelyi Plan was implemented river basin wide, including the Lower Tisza and the Serbian Section. One pillar of this project is the cleaning of the flooded area. Due to this measure more water will flow in that part of the cross-section, and any object, e.g. the Bridge of Ada will have a higher negative impact than nowadays.

The evaluation results of the Dam of Novi Bečej in low water situation numerically showed the significant influence it has on the upstream section. There is a lively debate at home and in the world on the effects of dams, whether they are useful or detrimental, so I cannot answer this question in this article, I only presented the rate of the water level increasing due to the damming in low water situation and in case of a failure.

This structure was made for damming in low and medium water situation; due to this fact it is not too high and cannot rise the water level not even in case of fully closed mode. Of course, in case of failure, the rising of the water level is highest directly by the dam, but the effect on the Hungarian sections is not negligible. The occurrence of extreme water levels always test the limits of the capacity of protection structures, so the slightest water level increasing means a high risk.

The researches show very well, the water management on river basin approach is the only one way in the border areas, in which all stakeholders' countries collaborate independently from the borders.

All measurements and natural phenomena (flood or low water situation) must be evaluated jointly taking into consideration the whole basin.

\section{References}

Gombos Béla (2011): Hidrológia-hidraulika. Gödöllö, Szent István Egyetem. Available: www.tankonyvtar.hu/hu/tartalom/tamop412A/2010-0019_hidrologia-hidraulika/ch18.html\#id516634 (Downloaded: 01.06.2019.)

Hungarian-Serbian-Montenegrin Water Management Committee (2006): A vízgazdálkodási együttmüködés 50 éve. Alsó-Duna-völgyi Vízügyi Igazgatóság.

National Atlas of Hungary (2018): Natural Environment. Budapest, Hungarian Academy of Sciences, Research Centre for Astronomy and Earth Sciences, Geographical Institute of Research.

Science Engineering and Sustainability (2019): HEC-RAS evolution. Available: https://sciengsustainability.blogspot.com/2016/08/some-months-ago-new-version-of-hec-ras.html (Downloaded: 01.06.2019.)

TIMBADIYA, Prafulkumar V. - PATEL, Prem Lal - POREY Prakash D. (2011): Calibration of HEC-RAS Model on Prediction of Flood for Lower Tapi River, India. Journal of Water Resource and Protection, Vol. 3, No. 11. 805-811. DOI: https://doi.org/10.4236/jwarp.2011.311090

WARA, Calvince - Thomas, Mike - MWAKURYA, Suleiman - KatuVA, Jacob (2019): Development of River Rating Curves for Simple to Complex Hydraulic Structure Based on Calibrated HEC-RAS Hydraulic Model, in Kwale, Coastal Kenya. Journal of Water Resource and Protection, Vol. 11, No. 4. 468-490. DOI: https://doi.org/10.4236/jwarp.2019.114028 


\section{Legal references}

$74 / 2014$ (XII. 23.) Regulation of the Ministry of Interior.

83/2014. (III. 14.) Korm. rendelet a nagyvízi meder, a parti sáv, a vízjárta és a fakadó vizek által veszélyeztetett területek használatáról, hasznosításáról, valamint a folyók esetében a nagyvízi mederkezelési terv készítésének rendjére és tartalmára vonatkozó szabályokról 